\title{
Virginie Mézan-Muxart, Genette et janette: devises de Jeanne de France au $\mathrm{XV}^{\mathrm{e}}$ siècle
}

\section{Paola Cifarelli}

\section{OpenEdition}

\section{Journals}

Édition électronique

URL : https://journals.openedition.org/studifrancesi/4613

DOI : $10.4000 /$ studifrancesi.4613

ISSN : 2427-5856

\section{Éditeur}

Rosenberg \& Sellier

\section{Édition imprimée}

Date de publication : 1 avril 2012

Pagination : 127

ISSN : 0039-2944

\section{Référence électronique}

Paola Cifarelli, «Virginie Mézan-Muxart, Genette et janette: devises de Jeanne de France au xv siècle », Studi Francesi [En ligne], 166 (I | LVI) | 2012, mis en ligne le 30 novembre 2015, consulté le 19 novembre 2021. URL : http://journals.openedition.org/studifrancesi/4613 ; DOI : https://doi.org/ 10.4000/studifrancesi.4613

Ce document a été généré automatiquement le 19 novembre 2021.

\section{(c) (i) (9)}

Studi Francesi è distribuita con Licenza Creative Commons Attribuzione - Non commerciale - Non opere derivate 4.0 Internazionale. 


\section{Virginie Mézan-Muxart, Genette et janette: devises de Jeanne de France au $X V^{\mathrm{e}}$ siècle}

Paola Cifarelli

\section{RÉFÉRENCE}

VIRGINIE MÉZAN-MUXART, Geinette et janette: devises de Jeanne de France au Xve siècle, «Reinardus», 22, 2010, pp. 104-125.

1 La genette, animal originaire d'Afrique assez semblable à un chat, apparaît dans l'iconographie médiévale dans des décorations marginales, des tapisseries, des vitraux; mais surtout, au Xve siècle, elle est utilisée comme devise de plusieurs princesses qui portent le prénom 'Jeanne'. L'A. analyse la devise parlante de Jeanne de France, fille de Charles VII et de Marie d'Anjou et épouse de Jean II de Bourbon, bibliophile et mécène, ainsi que l'emblème de Jeanne de Valois, nièce de la précédente et fille naturelle de Louis XI. Dans les deux cas l'animal est associé à une fleur, identifiée comme une janette (Lychnis dioica). Les manuscrits considérés sont les suivants: Paris, BnF, fr. 1847 (Livre de la mendicité spirituelle de Jean Gerson), fr. 227 (Boccace, De Casibus), Chantilly, Bibliothèque du Musée, 388 (Histoire d'amour sans paroles), La Haye, KB, 74 G 22 (Livre d'Heures de Jeanne de France). 